OPEN ACCESS

UNIVERSITY OF THE

WEST of SCOTLAND

UWS Academic Portal

\title{
Perspectives on theological education in Malawi
}

Matemba, Yonah

Published in:

Arts and Humanities in Higher Education

DOI:

$10.1177 / 1474022211408036$

Published: 01/07/2011

Document Version

Peer reviewed version

Link to publication on the UWS Academic Portal

Citation for published version (APA):

Matemba, Y. (2011). Perspectives on theological education in Malawi. Arts and Humanities in Higher Education, 10(3), 329-347. https://doi.org/10.1177/1474022211408036

\section{General rights}

Copyright and moral rights for the publications made accessible in the UWS Academic Portal are retained by the authors and/or other copyright owners and it is a condition of accessing publications that users recognise and abide by the legal requirements associated with these rights.

Take down policy

If you believe that this document breaches copyright please contact pure@uws.ac.uk providing details, and we will remove access to the work immediately and investigate your claim. 


\title{
PERSPECTIVES ON THEOLOGICAL EDUCATION IN MALAWI
}

\author{
Yonah H. Matemba \\ Lecturer in Education, University of the West of Scotland, UK \\ (Accepted for publication: Journal: Arts and Humanities in Higher Education, 10:3)
}

\begin{abstract}
This essay gives an overview of (Christian) Theological Education (hereinafter, CTE) in Malawi. To place the discussion in its appropriate context, information about Malawi is given including the impact of Christianity on the country. It then describes historical aspects of CTE and in that part of the discussion highlights some of inherent shortcomings of CTE. Shifting the discussion to more recent developments, the justification is made why Malawi still needs CTE. Next, attention is given to the two main 'routes' in the provision of CTE. Finally, 'new' theologies that have emerged in CTE in Malawi are identified and described.
\end{abstract}

KEYWORDS: Malawi, theological education, developments, paradigm shift

\section{BACKGROUND CONTEXT}

Malawi is a small country $(45,745$ sq. miles) in south-east central Africa but with a huge population $(15,263,417)$. It is ranked as one of the poorest in the world with a mere US\$ 596 average yearly income per capita (United Nations, 2009). Religiously, Malawi is pluralistic comprising Christians as the largest group (82.7\%: $54.3 \%$ Protestants and $28.3 \%$ Catholics), followed by Muslims (13.0\%) and then people belonging to other religions $(1.9 \%)$ such as African Traditional Religion (ATR), Bahaism, Hinduism, Sikhism, Rastafarianism, Judaism and Buddhism. 2.5\% of the population is said not to have a religion (Malawi Goverment, 2008).

Of all religions in the country Christianity has had a more enduring impact on people's socio-religious lifeworld. The origin of Christianity in Malawi is connected to a chance visit of the country by David Livingstone, the legendary Scottish missionary and explorer, who journeyed up the Zambezi and then Shire Rivers ending up on the shores of beautiful Lake Malawi on $17^{\text {th }}$ September 1859. It was Livingstone who called that Lake, Nyasa, a name that was later used to call the country 'Nyasaland' when it became a British Protectorate in 1891. The country's name later changed to Malawi after gaining independence in 1964 (Thompson, 2005) .

Practical beginnings of Christianity in Malawi are traced to the work Scottish Presbyterian missionaries who arrived in the mid-1870s and established two 
Christian centres, which exists to this day, namely, Livingstonia mission in the north (1875) and Blantyre mission in the south (1876) (Ross, 1996a). Although admittedly Scottish missionaries were 'children' of their time and as such they, too, can be accused for speeding up British colonisation of the country, it is worth pointing out that quite unlike other Europeans associated with colonial Malawi, the attitude of Scottish missionaries was always pro-African (Mufuka, 1977). For instance, Scottish missionaries sided with Africans in condemning the brutality unleashed on Africans accused of supporting the ephemeral 1915 uprising against the excesses of imperial rule led by the Malawian hero, Reverend John Chilembwe (Shepperson and Price, 1958). Scottish missionaries also supported Africans in condemning the Federation of Rhodesia and Nyasaland, a federal administrative merger of present Zambia, Zimbabwe and Malawi which operated briefly from 1953 and 1963 (Mufuka, 1977).

Worthy of note perhaps was the Presbyterian support of the proindependence movement in Malawi, from the late 1940s throughout the 1950s, and particularly its active support of Hastings Banda (b.1896-d.1997), a Scottish trained medical doctor who became the first president of Malawi on $6^{\text {th }}$ July 1964 and in his first cabinet, appointed a young Scottish lawyer, Colin Cameron, as minister for works, transport and communications (Ross, 1996a). However, shortly afterwards (August 1964) Cameroon and other ministers resigned their posts and fled the country when Banda's rule began to take an autocratic turn (Ross, 2009).

Returning to issue of Christian origins and influence in Malawi, we should note that by the turn of the twentieth century other Churches such as Baptist (1892), Seventh-day Adventist (SDA) (1902), Catholic (1903) had set up permanent bases as well (Shepperson and Price, 1958). As part of their social Gospel the various Churches built schools, clinics and industrial training centres many which are in operation to this day (Lamba, 1982). Historically, the Church in Malawi has been the major provider of modern education such that even to this day, $37 \%$ of all primary and secondary schools in the country are either owned or controlled by the various Churches (Matemba, 2011). In the health sector, the contribution of the Church has been equally noteworthy to the extent that $40 \%$ of the country's healthcare needs are provided by Churches which continue to run hospitals, clinics and vocational colleges for health workers. In addition, Churches have also been involved in development work, relief work, orphan care, care for the disabled and palliative care (Presbyterian Church of Ireland, 2009).

With a history of stretching back a century and half of activity, the impact of Christianity on Malawian society has been immense to the extent that it has shaped the country's national identity expressed in the adage that says Malawi is a God fearing country (van Doepp, 1998). So intertwined is Christianity with people's socio-cultural norms that rarely would a public or private function start and end without a prayer even if the nature of the function has no relevance to any matters of faith. During national elections politicians who ignore the Church by not making appearances at services in the different Churches or give Churches gifts of money, say for Church refurbishment, certainly risk losing votes of the Christian voting bloc (Noordin, 2009). Even at the time the country's president was a Muslim, Bakili Muluzi (1994-2004), his political survival largely depended upon votes of the large Christian community to the extent that prior to the 1998 
elections, which he won for a second term in office, not only did Muluzi frequent the Churches where he gave various gifts but that he also made an official visit to the Vatican, the first time a Malawian president had ever done so, perhaps in an attempt to woo the $28.3 \%$ Catholic Christians in the process (Sunni Council of Malawi, 2001).

In assessing the political developments in Malawi particularly in the mid1990s, the critical role played by the Church in helping to usher in a new political dispensation should be acknowledged. As we have noted, from the time the Malawi gained its independence from Britain, the country's political scene was dominated by the autocratic rule of President Banda. During Banda's long reign (1964-1992), anyone who did not tow the official political line of the one-party state with its emphasis on the cultic personality of the life president, suffered greatly. Imprisonment of political opponents, assassination of political 'dissents' and indeed anyone deemed to be an 'enemy' of the state was common place (van Doepp, 1998) .

Despite this acrimonious political situation Banda allowed the work of Churches to go on largely unhindered but of course as long as Churches stayed out of politics. This perhaps explains why years later when Banda's dictatorship became excessive on breaches of Human Rights, the Presbyterian Church in particular was at first reluctant to criticise him not only because it considered him one of its own (Thompson, 2005), but also due to genuine fear of persecution by Banda's ruthless state machinery of terror. In fact, in the early 1970s one Presbyterian minister, Jonathan Sangaya, died in mysterious circumstances for daring to suggest that Banda, who never married, should legalise his relationship with his live-in partner, Cecelia Kadzamira (Ncozana, 1999).

By the early 1990s Banda's autocratic rule began to crumble. While other factors should be considered for the collapse of his regime such as old age, economic sanctions from the west and a wave of democratic changes in the subSaharan region, the straw that broke the camel's back of Banda's autocratic rule was a Lantern Pastoral Letter of Catholic Bishops, entitled: Living Our Faith published in March 1992. Living Our Faith contained the most daring criticism of Banda's political establishment. Although at first the government frantically tried to arrest Catholic clergy and anyone possessing the document, the die was cast for Banda's once invincible government as civil unrest erupted and international pressure intensified (Mitchell, 2002).

The contribution of the Presbyterian Church to wider pro-democratic change in Malawi in the 1990s should also be noted. Despite the Churches' early hesitation about involvement in politics, after the 1992 Pastoral Letter the Presbyterian leadership was instrumental in the establishment of the Public Affairs Committee (PAC), a civil society group comprising Churches, Law society, Chamber of Commerce and Industry and Muslim Association. The significance of PAC was that not only did it give its full weight behind the Pastoral Letter but that it publically called for political reform at a time when it was still seditious to do so (Ross, 1996b). Following on from these dramatic events, in 1993 a referendum was held in which people unanimously voted for a multi-party system of democratic governance. A year later, democratic elections were held and Banda's once 
'mighty' Malawi Congress Party (MCP) lost to the United Democratic Front (UDF) party of Muluzi, a Muslim (Mitchell, 2002).

\section{EARLY DEVELOPMENTS IN THEOLOGICAL EDUCATION}

During the early years of the Church in Malawi the training of evangelists and preachers was provided as part of formal education in all the mission schools. At that time, mission education was essentially a means to Christian evangelisation because Church-operated schools adhered firmly to the policy of Christianity before literacy (Heyneman, 1972). Through this method, mission education offered by missionaries produced a pool of local evangelists and lay preachers who were then dispatched into the villages to help spread the Gospel to fellow Africans. The use of local evangelists and preachers, many of who opened up new centres of Christian work, had an immediate impact on the overall work of the Church. In reference to the work of African evangelists and lay preachers trained at Presbyterian mission schools, Andrew Ross has been noted that the same year (1891) Britain colonised Malawi there were 30 Africans in communicant membership but in just short six years, the numbers of new Christians in the Church had swollen to 400 (Ross, 1996a).

Some of the African evangelists who were trained through this way became prominent leaders in the Church in their own right. In 1900 the Presbyterian evangelist, Wilson Mwepeta, translated the Gospel of Mark into Lomwe (one of the local languages). Three years later his fellow Presbyterian, Charles Domingo, was ordained as the first African Licentiate in Malawi. In the SDA Church Peter Nyambo became a 'missionary' in his own right and helped in the opening of new mission stations for his Church not only in Malawi but in other African countries as well such as Kenya and Tanzania between 1907 and 1908 (Langworthy, 1996).

From available sources it seems that formal theological education in Malawi began after 1900 when some Churches set up theological schools for this purpose. In 1902 the Anglican Church launched a ship, Chauncey Maples, on Lake Malawi as floating theological school. The ship, however, did not provide a healthy environment to study as many of the students were constantly sea sick and as result in 1905, the Anglican Church opened St. Andrews Theological College on Likoma Island. For their part, Churches of Christ opened a theological school at Gowa mission in Ntcheu district in 1907 while Catholics opened their first theological college, St. Anthony in Mchinji district, in 1939 (Ross, 1995). The SDA Church opened its theological school at Malamulo mission in the 1940s before transferring the work to Lakeview mission a few years later while Likhubula Bible Institute, serving the various Evangelical Churches in Malawi, opened its doors in 1964 (Ross, 1995).

Casting CTE offered in the historically Church-operated schools in Malawi in a wider context, some of the shortcomings of traditional CTE should be noted. The term 'traditional CTE' is used here to denote the early types of CTE which the various Churches offered in the training of their clergy (Musopole, 1997). The first issue to note is that traditional CTE was Eurocentric in form. This means that CTE failed to contextualise the Gospel to the African situation. To a large degree CTE 
was inimical to African traditions because it advocated the complete abandonment of African culture apparently if Africans were to be saved from their heathen practices (Kalilombe, 1999). In such circumstances, failure to break with their traditional culture and embrace European culture wholesale, quite often resulted in Church discipline including excommunication. As a consequence, traditional CTE produced clergy who were made not to appreciate the pivotal role that African culture could play in the life and mission of the Church (Amanze, 2009b). It is for this reason that some indigenous Church leaders who detested the negative attitude towards African culture broke away from European led Churches and formed their own independent Churches where aspects of African culture were accepted not as the work of the devil but as a valid and positive element in understanding and expressing the Gospel the African way (Kalilombe, 1999).

Further, traditional CTE was partisan because each of the Church-owned theological schools offered its own particular denominational curriculum in which other religions and even other Churches were demonised as the proven example of religious falsity. Thus, in many ways CTE was designed to outscore and even eradicate the so-called false Churches and religions. In other words, traditional CTE was 'anti-ecumenical, inward looking ... [and] protectionist' (Amanze, 2009a, p. 5). Another deficiency of traditional CTE was that the curriculum offered put too much emphasis on evangelism, homiletics, liturgy and mnemonics. Some aspects of this model are still evident today in what I have described below as the 'professional' route of CTE. For example, at the Free Methodist Bible school, graduation is strictly dependent upon the student's ability to plant three or more functioning Churches (Church, 2002).

The final point to be made about traditional CTE is the fact that it perpetuated the marginalisation of women. James Amanze, a Malawian theologian, has noted that traditional CTE failed to challenge patriarchal theologies a development which in turn has historically contributed to the inferiorisation of women in the Church, preventing them from participating fully in the ministry of Christ (Amanze, 2009a). In recent decades, however, patriarchal attitudes in the Church in Malawi have been challenged. Isabel Phiri, Malawi's first female theology professor, has critiqued patriarchal theology for its fondness to conservative Christologies. She has demonstrated how patriarcholism in theology, the use of traditional culture and reliance on selected biblical passages have historically perpetuated oppressive tendencies against women (Phiri, 2007).

In her writings, Phiri has sharply criticised her own Presbyterian congregation for its failure to bring equality between men and women in the Church, pointing out that women are under-represented in the decision making bodies and that the few women that are in such positions are treated merely as tokens (Phiri, 1996). Phiri has rallied African women to stand up against patriarchal practices in the Church emphasising that they should refuse to remain with the image of a suffering Christ as their liberator. She has urged women to 'arise and love themselves as they love others' because 'Christ the liberator does not call African women to remain at the cross and suffer with him'. Rather, she continues to say, African women are 'called to climb the cross and be lifted up to view the world with Jesus' for the fact that 'Jesus' suffering was for a purpose [which was] to bring deliverance’ (Phiri, 1998, p. 212). 
What impact there has been on the Church and society arising from the debates around the issue of women empowerment forms part of the last section in this essay to which I will later return, but for now let us consider why I maintain that Malawi needs CTE even today.

\section{THE NEED FOR THEOLOGICAL EDUCATION TODAY}

A number of factors can be suggested as to why today Malawi still needs CTE. First, assessing current political developments in post-dictatorship Malawi, it is evident that Malawi needs well trained clergy that is able to engage effectively with complex political, social and religious issues in its contemporary society. I argue that while many positive things have happened since the dictatorship years of two decades ago-for example, that the country is able to hold presidential and parliament elections and that generally there is rule of law-it is evident that problems remain as highlighted in the latest (October 2010) Pastoral Letter of Catholic Bishop.

Since the 1992 inaugural Pastoral Letter noted earlier in this essay, Catholic Bishops in Malawi have released 19 other Pastoral Letters. However, none of these has been as critical of government as the current issue, entitled: Reading Signs of the Times: Current Socio-Political and Economic Issues in Malawi (Catholic Bishops, 2010). Reading Signs of the Times points out some concerns among them: (a) lack of proper consultation on national issues, (b) politically targeted anticorruption drive and (c) harassment of the vice-president who has since been fired from ruling party accused of forming parallel party structures. Concerning the vice-president, it has emerged that the real reason behind her predicament is that she has refused to endorse the president's younger brother, a minister in the government, as the party's next presidential candidate because she has ambitions to run for president herself at the expiry of the incumbent presidents' two mandated presidential terms in 2014 (Wezzi, 2010).

Gauging the manner in which the government has reacted to this Pastoral Letter, it is clear that the Catholic Church has ruffled feathers with the government of the current president, a Presbyterian recently converted to Catholicism. For instance, the government has publically rubbished the contents of the Pastoral Letter describing them ill-advised and wrong and generally has told the Church to stay out of politics (Malawi Government, 2010). It seems to me that the boldness with which the Catholic Church leadership has addressed the issues it considers to be of national 'concern' and the manner in which the government has reacted to the criticism, illustrates the fact that in Malawi, as in much of subSaharan Africa where democratic institutions remain weak (Knusten, 2010), the Church will continue to need qualified leadership that is able to provide a critical voice to the political status quo, even in what is supposed to be a democratic era, because individual citizens are afraid to express their political views freely lest they fall victim to politically motivated harassment and financial ruin by the ruling political elite.

The other justification for CTE is that Malawi has a huge Christian membership (and growing) and thus needs to train more ministers. To give some context, Christian membership in the country has climbed from $79.9 \%$ in 1998 to 82.7\% in 2008 and currently there are some 10 million Christians who worship in 
more than 55 different denominations (Malawi Goverment, 2008). Although published figures of the number of ministers Churches in Malawi actually need are unavailable, anecdotal evidence suggests that there are few ministers to go around this growing religion as seen by the fact in most Churches a single minister is incharge of several large congregations (Church, 2002).

Finally, CTE is needed in Malawi to supplement the shortage of Religious Education (RE) teachers. The RE curriculum in Malawi remains Bible based. In fact, a recent attempt to replace the historical BK syllabus with a multi-faith one in the secondary school curriculum has been resisted by key stakeholders such parents and Churches (Matemba, 2011). However, owing to inadequate space in further education the country produces not more than 450 secondary teachers annually. According to government reports there are only 3,500 qualified secondary school teachers in the school system in Malawi and that to meet demand the secondary school sector alone would require an additional 25,000 trained teachers (MME, 2008).

Thus, for a subject such as RE that is perceived to be of low academic status, the shortage of teachers is acute. One of the main reasons for this situation is that few RE teachers are being trained. During 2009/2010 academic year, for example, only two students enrolled to train as secondary school RE specialists at the University of Malawi (UNIMA). During the same period, the Catholic University of Malawi enrolled three students wishing to specialise in RE in its training programme. It is for this reason that RE in most Malawian schools is taught either by unqualified teachers (i.e. only with the ' $O$ ' Level Certificate or less) or theology graduates. Given this scenario, it is evident that CTE is needed in Malawi to train more theology graduates who can be employed to teach RE in schools than depend on unqualified staff as presently is the case (Matemba, 2011).

\section{TWO 'ROUTES’ OF THEOLOGICAL EDUCATION}

In this essay I distinguish between two generic routes in the provision of CTE in Malawi. The one route is what I see as the classical CTE which, historically, has been the preferred route by Churches in the training of their clergy for the ministry. Classical CTE follows a traditional model of ministerial training in which the curriculum is denominational in design and evangelical in nature. One distinguishing feature of classical CTE is that it is offered in Bible colleges or seminaries which individual Churches operate. In Malawi today the Catholic Church has a number of seminaries as do other Churches such as Nazarene, Baptist, Evangelical, Pentecostal, SDA, Seventh-day Baptist, Assemblies of God and Lutheran which also have their own Bible colleges. In total, there are more than 24 different theological schools operated by the Churches that follow the classical route of CTE (see Muyangata, 2008, Ross, 1995).

Another feature of classical CTE is that it emphasises professional rather academic theological training. Putting it in another way, its main interest is the training of ministers for their Churches and as such there is little emphasis on the academic merit as condition for admission for training. In most cases students with only a primary school leaving certificate (obtained after eight years of primary education) or junior secondary certificate (obtained after two years of secondary education) are generally accepted as meeting the minimum educational 
qualifications for admission into ministerial training (Ross, 1995). What is important to these Church-owned Bible colleges are a person's dedication to ministry, eagerness to evangelise and passion to promote one's Church and not just academic merit (Church, 2002). I must be quick to note that academic entry standards are improving in many of the Bible colleges which now require students to have at least the terminal Malawi School Certificate of Education (MSCE) (equivalence of British ' $O$ ' levels). However, the reality is that many students with excellent MSCE passes would rather go to university than to a Bible college.

The other route is what I see as post-classical CTE. In contrast to the classical one, post-classical CTE is offered in institutions of higher learning. I use the term 'institutions of higher learning' to refer to universities or colleges in Malawi which offer academically demanding education in theology and after a period of study a university diploma or degree is awarded. Academic standards for entry into the post-classical institutions are usually high. In Malawi institutions that offer post-classical CTE include UNIMA (public), Mzuzu University (public), Domasi College of Education (public), Catholic University (private), Livingstonia University (private) and African Bible College (private).

One other institution that offers post-classical CTE worth mentioning at this point is Zomba Theological College. The circumstances for this college to offer a university credited qualification in theology should be noted. The institution opened in 1972 as a Bible College of the Churches of Christ under the name United Theological College. Five years later the Presbyterian Church joined as co-owner of the college under the current name. In 1978, the Anglican Church became the third denomination to join in the management of the college. After the department of Theology and Religious Studies was opened at UNIMA in 1991, Zomba Theological College entered into an affiliation arrangement with UNIMA and the agreement, which stands to this day, stipulates that students at the college follow a course validated by the university and upon completion of the course are awarded a UNIMA diploma (Ross, 1995).

Another distinguishing feature of post-classical CTE is interdenominationalism. First, the courses they offer follow an inter-denominational curriculum in which no one Church doctrine dominates what is taught. Thus, what is offered is what can be described as 'general' Christian curriculum. Another inter-denominational aspect of post-classical CTE is that teaching staff is drawn from people belonging to different Churches and in some cases from different religions altogether, as in the case of UNIMA which has a Muslim lecturer on its staff (Chakanza, 2008). A third aspect of inter-denominationalism in post-classical CTE is that students attending the programmes come from different denominations, religions and in some cases students with no professing faith at all.

\section{PARADIGM SHIFT IN THEOLOGICAL EDUCATION}

During the past four decades or so there has been a paradigm shift in CTE in Malawi. Two determining factors can be cited for this. The first factor concerns developments related with the end of colonial rule in Malawi from the mid-1960s which subsequently led to the decline of missionary influence and the rise of 
indigenous leadership in the management of the Church. From an African perspective, one of the positive outcomes of these administrative changes was that the new African leadership began to promote Africanised forms of Christian expression.

African Independent Churches excepted, among the historically missionary Churches this paradigm shift is perhaps more pronounced in the Catholic Church where Catholic Bishops have embraced inculturation in toto. In turn this has engendered Africanised styles of worship expressed through the beating of African drums, clapping of hands and even some dancing during worship. The consecration of Malawian Bishops today aptly illustrates how far Catholic Church leaders have embraced their African roots. To name but one example, consecration ceremonies have become colourful affairs complete with the new Bishop decked in animal skins and other traditional paraphernalia while African brewed beer flows freely at the event (Kalilombe, 1999). What this demonstrates is that while traditional African culture in Malawi was seen by missionaries as obstacles to the Christian faith (Matemba, 2010), in the post-colonial/missionary dispensation this is welcomed by the indigenous leadership who see it as key to progress in the Church (Kalilombe, 1999).

The second factor to be considered has been the impact of globalisation on the Church in Malawi. The 'global village'-in part characterised by an increase in the number of African Church leaders trained in Western countries where social changes have been dramatic since the end of the Second World War; instant communication through internet technology; and finally, rapid inter-regional and inter-continental travel-has had an immense influence in the way both Church leaders and theological educators in Malawi now engage with societal issues. Thus, while theological educators in Malawi, as elsewhere in Africa, have been striving to develop indigenous Christian theologies clearly their worldview has been has impacted by the way the global society in general is also dealing with similar topical issues such as gender, multiculturalism, HIV/AIDS, ecumenism, Human Rights and so on (Amanze, 2009a).

As in Ghana (Atta-Baffoe, 2008), CTE in Malawi has responded to these pertinent issues by including 'new' theologies in their theological programmes. Many of these new theologies have emerged as sub-sets of the broader field of 'contextual' or 'practical' theology. By 'contextual' or 'practical' theology I mean a relevant theology that is cooked in an 'African pot'1 (Fiedler et al., 1997). Augustine Musopole, a Malawian theologian, contends that contextual theology in Africa focuses on the "cultural context of both students and the people they are going to evangelise' (Musopole, 1997, p. 10). While African scholars have suggested a number of theologies that may add further value to CTE in general, my task in this section is to actualise the situation by making specific references only to those theologies that are currently being offered in CTE in Malawi.

\footnotetext{
1 The phrase 'cooked in Africa pot' was the theme of the 1996 Association of Theological Institutions in Southern and Central Africa (ATISCA) conference where a number of papers regarding how theology can be 'Africanised' were read.
} 
The first new theology we should consider in this essay is the fight against HIV/AIDS. Issues about the devastating effects of this disease in Africa are well documented and will not be repeated except to add the point that the fight against HIV/AIDS has become a new 'call' in CTE in Malawi (Muyangata, 2008). At Zomba Theological College students are taught the social and ethical context in which the pandemic is spreading and cautioned not to be judgemental over the issue. They are taught skills that enables them to preach a theology of hope and not previously when the college taught a theology of doom and retribution in connection with the disease (Thipa, 2009). The issue of emphasising 'compassion' as opposed to the 'blame' related to HIV/AIDS has been highlighted in a recent paper which has noted that since almost everyone in the country has been affected by the scourge, blame only adds an unnecessary psychological component to pervasive suffering, and concludes that only a 'theology of compassion' is needed to help reduce isolation through practical human connections (Morris et al., 2009).

Another emergent theology in CTE in Malawi is African Christian theology. While in the past ATR was condemned in its totality as heathen by missionaries and some early African Church leaders, today African theologians and Church leaders point out its salvific value. Patrick Kalilombe, a retired Malawian Catholic Bishop, has implored the Church to take African religion seriously. In many of his writings he has explored the value of cultural traditions to African Christians (Kalilombe, 1999). Jesse Mugambi, a Kenyan theologian, emphasises the fact that today the Church in Africa recognises that if Christian experiences are to be 'meaningful and affective, people cannot afford to cut themselves off from the rest of the community or from their own cultural and religious past' (Mugambi, 1994, p. 10). As a response, the course titled 'African Religion' is offered on the programmes of most post-classical CTE in Malawi.

Religious pluralism and plurality is another new theology that has emerged in CTE in Malawi. In a country with a Christian majority but also having an assertive Muslim minority intra-religious tension between Christians and Muslims are common particularly in the so called 'religious hot' spots which are areas with large Muslim populations. One area where such a problem is often reported is Mangochi district, the historical headquarters of Malawian Muslims and where the majority of Muslims in the country live. To give some context about Mangochi, of the 803,602 people in the district Muslims are in a huge majority at $69.8 \%$ while Christians make up 28.7\% (17.9\% Catholics) of the population (Malawi Goverment, 2007). Inter-religious conflict in Mangochi between Muslims and Christians occur from time to time. In the wake of the September $11^{\text {th }}$ atrocities five Muslim men (all foreigners working for Muslims organisations) were arrested in June 2003 and handed over to US agents for onward transfer to Guantanamo Bay detention centre in Cuba. In reaction to these arrests, local Muslims in the district became violent where upon they burnt down five Churches and destroyed several vehicles belonging to Christians. The Catholic Church which has a visible presence in the district through the operation of schools (i.e. 75\% of all primary and secondary schools), clinics and a radio station (only Catholic radio station in the country) bore much of the Muslim anger in the 2003 episode (Malawi Goverment, 2007). In a more recent incident (October 2010), Muslim parents in the district publically tore up Bibles given to their children at school by the missionary group, Gideon's' International (Mponda, 2010). As a response to inter-religious tensions in Mangochi 
district a number of inter-faith initiatives sponsored by the government and organizations such as Deutsche Gesellschaft für Technische Zusammenarbeit (GTZ) and the Roman Catholic Church's 'Centre for Social Concern' have been providing inter-faith dialogue training to faith leaders and lay members of the two religious communities in the district (Umar et al., 2008).

Returning to the issue of religious pluralism and plurality, it is necessary to note that while in the past CTE in Malawi put too much emphasis on the theological superiority of Christianity over other religions the attitude has changed because today religious pluralism is being preferred over religious exclusivism. CTE in the country now apportions time for the study of other religions as a way of stressing the value of multiculturalism in society. Some of the new theological courses being taught in CTE include a course on 'world religions' where religions such as ATR, Islam, Hinduism and several others are offered.

Ecumenism is another topical theology now being offered in CTE in Malawi. It should be noted that during the formative years of the Church in Malawi denominational disputes were not uncommon. The main cause of these disputes stemmed from Churches accusing each other of trespassing into each other's self declared 'evangelical territories'. The situation had become so bad that by the first half of the twentieth century the colonial government was forced to act to keep the peace by imposing a two-mile limit between schools or out-missions of the different Churches to prevent against this sort of problem re-occurring between the different denominations (Reijnarts et al., 1997).

Another historical area of contention among the various denominations had to do with the provision of RE (i.e. Bible Knowledge, hereinafter, BK) in schools. The problem was that Churches could not agree on a common material outline for schools. The issue was so acrimonious between the Churches that despite the fact that education was centralised by the colonial government in 1927, each Church continued to teach a separate denominational RE syllabus in its schools (Nyasaland Government, 1946).

In addition, even when other denominations desired to have ecumenical relations some Churches, the SDA Church in this case, flatly refused to join such groupings citing theological objections to any ecumenical activity (Schwarz, 1979). Today, relations among Churches is much improvised through ecumenical groupings such as Malawi Council of Churches established in 1942 and Christian Health Association of Malawi (CHAM) established in 1966 (Malawi Council of Churches, 2009). Examining courses offered in the various CTE in Malawi it is evident that ecumenism is taught in most of the theological schools (see Ross, 1995).

The other new theology in CTE is about the environment. There is no denying the fact that in Malawi environmental degradation (i.e. deforestation, pollution, soil erosion, poaching and over-fishing) has detracted the country's beauty and depleted its natural resources. As a general response to what is clearly an issue of national concern, the Church has called upon people to play their part in the battle to safeguard the environment. The Church is hopeful that through its leadership, society might come to understand that nature and the environment are God's creation which needs people's protection (Chakanza, 2009). 
A number of theological institutions in the country now include a course on environmental education on their programmes. The Catholic University offers a course titled 'Religion and Environmental Issues'. Similarly, Mzuzu University has a course titled 'Religion and the Environment'. More generally, the issue of environmental degradation should be commented on further. Clearly many environmental challenges such as deforestation remain due to the country's heavy dependence on firewood and makala (charcoal) as energy sources (Moyo and Ott, 2002). While it is difficult to make an overall assessment of the efficacy of the environmental movement and even how effective the Church has been with its message on environmental protection on grassroots communities, there have been some positive developments. In the national budget of 2009/20100 the government removed customs duty on solar equipment and wind-mill engines to encourage people to use less corrosive and environmental friendly sources of energy (MRA, 2010). Non-governmental groups are also making a positive practical impact on the environment. For example, the Mulanje Conservation Trust funded by the Norwegian government, runs a successful afforestation program in the Mulanje district area (Nyasa Times, 2010).

Peace, justice and Human Rights is another new theology that has emerged in CTE in Malawi. At this point we should be reminded that as one of the least developed countries in the world, poverty in Malawi is a depressing reality. Again, inequality between the few haves and many have-nots seem to be forever widening. These are also issues that the Church has been speaking about in condemning the excesses of the few and highlighting the plight of the majority of Malawians (53\%) who live below the poverty line (Central Intelligence Agency, 2009). In recent decades CTE in some institutions has given attention to political, social and economic issues in the country. In light of this, theological institutions have developed courses around issues such as equality, freedom, peace, economic egalitarianism and democratisation. At the Catholic University this theology is taught under the course 'Catholic Social Teaching'. Zomba Theological College also teaches a course that covers issues such as peace, justice and Human Rights.

The last but by no means least new theology that has emerged in CTE in Malawi is feminism. As noted previously, feminist theologians in Malawi have been calling for an end to the marginalisation of women in the Church. It is therefore with some relief to note that the on-going theological debates on gender and women empowerment in the Church in Malawi-not least through the work of Malawian female and male theologians in some of the universities offering theological education notably UNIMA, Mzuzu and Catholic-for supporting feminist theology as an academic discipline of study. The teaching of feminist theology in CTE and debates round the whole issue of gender and women empowerment by feminist theologians and gender activists seem to have pricked public consciousness about the need to give women issues the attention that is necessary in Malawi. In Malawi today one finds cases, isolated as they maybe, of women being ordained with full rights to the priesthood in their Churches. We also find instances where sermons of women preachers are being televised (Phiri, 1998).

Although attitudes towards women empowerment in the Church in Malawi are showing signs of positive change, challenges remain. The perversity of patriarchal culture not only in the Church but in the wider society perhaps remains 
the reason men have not taken up the cause of women empowerment as vigorously as women have on this issue. However, it seems that this challenge is not unique to Malawi but in other countries as well. In the United States, for instance, conservative elements in some Churches do not support the idea of women having leading roles (Bendroth, 2001). Therefore, as in Uganda it seems that on the whole the reality for women in Malawi remains that while it is God who calls them to serve in the Church, actually it is men who ordain them (Byaruhanga, 2010). Putting this differently, Church government and leadership structures in Malawi, as elsewhere on the African continent, continue to be guided by patriarchal structures and protocols set up by men with no or little input from women (Muwamba, 2010).

Given the perversity of traditional culture in Malawi and its associated societal norms and perceptions which make women perpetually subordinate to men, meaningful changes towards progress for women not only in the Church but in the general society as well, will take a long time to be realised (Tiessen, 2008). What is also evident is that despite the rhetoric about the changing status of women in the Church the actual numbers of women holding leadership positions remain insignificantly low. In fact, besides independent Christian ministries where women hold leadership positions of the Churches of which they are founders, no mainline Church (i.e. missionary Churches) in Malawi has ever had a woman as its overall national leader. In many cases the situation for women in Church employment in mainline Churches remains pretty much unchanged. In one infamous case, for example, conservative male members in the SDA Church in Malawi prevented the Church's director of Women's Ministries to preach quoting the Bible saying that it is 'against scripture for women to do so' (Dabrowski and Bilima, 2000, p. 1).

My view is that in order to deal effectively with some of these challenges for women in the Church deliberate efforts should be made to sensitise men, particularly those in Church leadership, about the benefits of having women as equal partners in the propagation of the Gospel. It may be helpful if the Church could begin to sponsor men to specialise in feminist theology. Reports that some male students in post-classical CTE particularly at UNIMA have started to choose dissertation topics in feminist theology should be lauded because having men studying feminist theology might be the small but important step that can help to counteract the impression that gender issues in theology-and by implication women issues in the wider public-are the concern and benefit only for women or female theologians, which clearly are not.

\section{CONCLUSION}

The purpose of this essay has been to provide an overview of CTE in Malawi and, as such, it may not have covered all pertinent issues related to CTE in the country. However, to the extent that this essay documents a previously ignored research area, I am sure that the issues that have been discussed reveal not only the state of CTE in Malawi but perhaps what is happening elsewhere in sub-Saharan Africa as well. 


\section{REFERENCES}

AMANZE, J. 2009a. Globalisation of Theological Education and the Future of the Church in Africa: Some Critical Reflections towards Edinburgh 2010 and its Aftermath:

http://www.google.com/search?hl=en\&source=hp\&q=james+amanze+theolo gical\&aq=f\&oq=\&aqi 5th November 2009.

AMANZE, J. 2009b. Paradigm Shift in Theological Education in Southern and Central Africa and its Relevance to Ministerial Formation. International Review of Missions, 98, 120-131.

ATTA-BAFFOE, V. 2008. Ministerial Formation and Theological Education in Ghana: Prospects and Challenges. Journal of Anglican Studies 6, 41-48.

BENDROTH, M. 2001. Last Gasp Patriarchy: Women And Men In Conservative American Protestantism. The Muslim World, 91, 45-54.

BYARUHANGA, C. 2010. Called by God but Ordained by Men: The Work and Ministry of Reverend Florence Spetume Njangali in the Church of the Province of Uganda Journal of Anglican Studies 8, 219-239.

CATHOLIC BISHOPS 2010. Pastoral Letter: Reading the Signs of the Times: Current Socio-Political and Economic Issues in Malawi, Episcopal Conference of Malawi, 31st October.

CENTRAL INTELLIGENCE AGENCY 2009. World Factbook: Malawi: https: / /www.cia.gov/library/publications/the-world-factbook/. Accessed 30th November 2009.

CHAKANZA, J. 2008. Annual Report for 2007-2008 Academic Year: University of Malawi, Department of Theology and Religious Studies. Zomba: Chancellor College.

CHAKANZA, J. 2009. Climate Change and Environmental Degradation: SocioCultural and Theological Perspectives. Religion in Malawi, 15, 15-38.

CHURCH, H. 2002. Theological Education that Makes a Difference: Church Growth in the Free Methodist Church in Malawi and Zimbabwe, Blantyre, CLAIM.

DABROWSKI, R. \& BILIMA, K. 2000. Women in the Pulpit Issue Splits Congregation in Malawi, Adventist News Network, 25th July. .

FIEDLER, K., GUNDANI, P. \& MIJOGA, H. 1997. Theology Cooked in an African Pot, ATISCA Bulleting No. 5/6, Special Volume, Limbe, Malawi, Assemblies of of God Press.

HEYNEMAN, S. 1972. The formal school as a traditional institution in an underdeveloped society: the case of Northern Malawi. Paedagogica Historica, 12, 460-472.

KALILOMBE, P. 1999. Doing Theology at the Grassroots: Theological Essays from Malawi, Gweru, Zimbabwe, Mambo Press.

KNUSTEN, C. H. 2010. Africa's Growth Tragedy Revisited: Weak States and Strong Rulers. Department of Political Science, University of Olso (unpublished).

LAMBA, I. 1982. African Women's Education in Malawi, 1875-1952. Journal of Educational Administration and History, 14, 46-54.

LANGWORTHY, H. 1996. "Africa for the Africans": The Life of Joseph Booth, Blantyre, CLAIM. 
MALAWI COUNCIL OF CHURCHES 2009. Malawi Council of Churches Report. Document uploaded at: http://www.oikoumene.org/en/memberchurches/regions/africa/malawi/mcc.html. Accessed 30th November 2009.

MALAWI GOVERMENT 2007. Mangochi District Assembly: District Education Plan (DEP) - 2008/2009-2010/2011. Mangochi: Mangochi Disctrict Assembly.

MALAWI GOVERMENT 2008. Malawi: 2008 Population and Housing Census. Zomba: National Statistical Office.

MALAWI GOVERNMENT 2010. 'Reading Signs of the Times': A Response by the Government of the Republic of Malawi, Lilongwe, 7th December.

MATEMBA, Y. H. 2010. Continuity and change in the development of moral education in Botswana. Journal of Moral Education, 39, 329 - 343.

MATEMBA, Y. H. 2011. A Comparative Study of Religious Education in Scotland and Malawi with Special Reference to Developments in the Secondary School Sector, 1970-2010. PhD (unpublished), University of Glasgow.

MITCHELL, M. 2002. " Living Our Faith:" The Lenten Pastoral Letter of the Bishops of Malawi and the Shift to Multiparty Democracy, 1992-1993. Journal for the Scientific Study of Religion, 41, 5-18.

MME 2008. The Development of Education in Malawi: A National Report. Lilongwe: Ministry of Education.

MORRIS, L., SCHELL, E., SCHELL, D., RANKIN, S. \& CHAKANZA, J. 2009. Theologies of Blame and Compasssion in the Response of Religious Organisations to the AIDS Crisis in Malawi, Central Africa. Religion in Malawi, 3-10.

MOYO, F. \& OTT, M. 2002. Christianity and the environment: Care for what you have been given, Blantyre, CLAIM.

MPONDA, J. 2010. Muslims angered with Gideon International for Converting them into Christianity, Malawi Voice, 6th October. .

MRA 2010. Malawi Revenue Authority tarrif amendments. Website accessed at http://www.mra.mw/customs_tariff_amendments.php on 29th January 2010.

MUFUKA, K. 1977. Missions and Politics in Malawi, Ontario, Limestone Press.

MUGAMBI, J. N. K. 1994. J.N.K. Mugambi, African Christian Theology: An Introduction, Nairobi, East African Educational Publishers.

MUSOPOLE, A. 1997. Theology Cooked in an African Pot, ATISCA Bulleting No. 5/6, Special Volume. In: FIELDER, K., GUNDANI, P. \& MIJOGA, H. (eds.). Limbe, Malawi: Assemblies of of God Press.

MUWAMBA, E. 2010. How Free are Womem to Preach in a Congregation?, The Nation, 25th November.

MUYANGATA, J. 2008. Mainstreaming HIV and AIDS in Theological Education: A Case of Evangelical Institutions in Malawi. In: CHITANDO, E. (ed.) Mainstreaming HIV and AIDS in Theological Education: Experiences and Explorations. Geneva, Switzerland: World Council of Churches.

NCOZANA, S. 1999. Sangaya: A Leader in the Synod of Blantyre Church of Central Africa Presbyterian, Blantyre, CLAIM.

NOORDIN, A. 2009. Cabinet Quota Upsets Malawi Muslims, Nyasa Times, 18th June. http://www.nyasatimes.com/national/cabinet-quota-upsets-malawimuslims.html. Accessed 9th September 2010.

NYASA TIMES 2010. Bunda college joins global experts on climate change predictions, 5th February. .

NYASALAND GOVERNMENT 1946. Annual Report of the Educational Department for the Year 1946. Zomba. 
PHIRI, I. 1996. Marching, Suspended and Stoned: Christian Women in Malawi in 1995. In: ROSS, K. (ed.) God, People and Power in Malawi: Democratisation in Theological Perspectives. Blantyre: CLAIM.

PHIRI, I. 1998. Christianity: Liberative or Oppressive to African Women. In: ROSS, K. (ed.) Faith at the Frontiers of Knowledge. Blantyre: CLAIM.

PHIRI, I. 2007. Women, Presbyterianism and Patriarchy: Religious Experience of Chewa Women in Central Malawi, Blantyre, CLAIM.

PRESBYTERIAN CHURCH OF IRELAND 2009. Malawi: Mission Oversees, http://www.pcimissionoverseas.org/partners/item/4/church-of-centralafrica-presbyterian-ccap/. Accessed 15th February 2010.

REIJNARTS, H., NIELSON, A. \& SCHOFFELEERS, M. 1997. Montfortians in Malawi: Their Spirituality and Pastoral Approach, Blantyre, CLAIM.

ROSS, A. 1996a. Blantyre Mission and the Making of Modern Malawi, Blantyre, CLAIM/Kachere.

ROSS, A. 2009. Colonialism to Cabinet Crisis: A Poltical Hisotry of Malawi, Zomba, Kachere Series.

ROSS, K. 1995. Church, University and Theological Education in Malawi, Zomba, Kachere Books.

ROSS, K. 1996b. God, People and Power: democratisation in theological perspectives, Blantyre, CLAIM.

SCHWARZ, R. 1979. Light Bearers to the Remnant, Mount View, California, Pacific Press Publishing Association.

SHEPPERSON, G. \& PRICE, T. 1958. Independent Africa: John Chilembwe and the Origins, Setting and Significance of the Nyasaland Native Rising of 1915, Edinburgh, Edinburgh University Press.

SUNNI COUNCIL OF MALAWI 2001. The Sheikh's letter to His Excellency President Bakili Muluzi: The Thirteen Signatory Sheikh's Potry Muluzi's Person and Policies during His Reign since 1994. Blantyre: Sunni Council of Malawi.

THIPA, J. A. 2009. Interview, Deputy Principal, Zomba Theological College, Zomba, 15th September.

THOMPSON, T. J. 2005. Presbyterians and Politics in Malawi: A Century of Interaction. The Round Table, 94, 575-587.

TIESSEN, R. 2008. 'Small Victories But Slow Progress': An Examination of Women in Politics in Malawi. International Feminist Journal of Politics, 10, 198-215.

UMAR, E., JERE, T. \& MANDALAZI, P. (eds.) 2008. Religious Conflict in Mangochi: An Assessment of the Current Religious Tensionin Mangochi District, Lilongwe, Malawi: Centre for Social Concern of the Missionaries of Africa.

UNITED NATIONS 2009. Countries of the Third World: United Nations online, http://www.nationsonline.org/oneworld/third_world.htm. Accessed on 29th November 2009.

VAN DOEPP, P. 1998. The Kingdom Beyond Zasintha: Churches and Political Life in Malawi's Post-authoritarian Era. In: PHIRI, K., \& ROSS, K., (ed.) Democratisation in Malawi: A Stocktaking. Blantyre: CLAIM/Kachere.

WEZZI, A. 2010. Joyce Banda had to go: DPP delivered, Maravi Post, 29th December. 